\title{
Entrepreneurship and COVID-19: Opportunities in the pandemic
}

\author{
Empreendedorismo e COVID-19: Oportunidades na pandemia \\ Emprendimiento y COVID-19: Oportunidades en la pandemia
}

Received: 10/30/2021 | Reviewed: 11/07/2021 | Accept: 11/19/2021| Published: 11/28/2021

\author{
Anderson Lopes Nascimento \\ ORCID: https://orcid.org/0000-0003-2538-9000 \\ Universidade Federal do Piauí, Brazil \\ E-mail: adm.anderson@hotmail.com \\ Sérgio Castro Gomes \\ ORCID: https://orcid.org/0000-0002-1731-8766 \\ Universidade Federal de Viçosa, Brazil \\ E-mail: sergio.gomes@unama.br \\ Antônio Vinícius Oliveira Ferreira \\ ORCID: https://orcid.org/0000-0001-9571-8784 \\ Faculdade FUCAPE, Brazil \\ E-mail: antvinicius@ufpi.edu.br \\ Ana Luiza Carvalho Medeiros Ferreira \\ ORCID: https://orcid.org/0000-0001-8616-7570 \\ Faculdade FUCAPE, Brazil \\ E-mail: analuizacmedeiros@gmail.com \\ Fábio da Silva \\ ORCID: https://orcid.org/0000-0003-0039-0128 \\ Universidade Potiguar, Brazil \\ E-mail: fabiosoyme@hotmail.com \\ Tarciara Magley da Fonseca Pereira \\ ORCID: https://orcid.org/0000-0002-7570-8471 \\ Universidade Potiguar, Brazil \\ E-mail: tarciara@ufersa.edu.br \\ Carlos Dias Chaym \\ ORCID: https://orcid.org/0000-0002-8685-4650 \\ Faculdade Cearense, Brazil \\ E-mail: carlosdiaschaym@gmail.com \\ Maria de Lourdes de Melo Salmito Mendes \\ ORCID: https://orcid.org/0000-0001-6881-6928 \\ Universidade Federal do Piaú, Brazil \\ E-mail: admsalmito@ufpi.edu.br \\ Michel Zahn Araújo \\ ORCID: https://orcid.org/0000-0003-0750-7894 \\ Universidade da Amazônia, Brazil \\ E-mail: euaraujomichel@gmail.com \\ Kelsen Arcângelo Ferreira e Silva \\ ORCID: https://orcid.org/0000-0003-1892-9160 \\ Universidade Federal do Piauí, Brazil \\ E-mail: Kelsen@ufpi.edu.br \\ Juliana Carvalho de Sousa \\ ORCID: https://orcid.org/0000-0002-0388-3959 \\ Universidade Potiguar, Brazil \\ juli.cs1009@gmail.com \\ Thiago Assunção de Moraes \\ ORCID: https://orcid.org/0000-0001-9729-4858 \\ Universidade Federal da Paraíba, Brazil \\ E-mail: thgmoraes@gmail.com
}

\begin{abstract}
This paper aims to investigate the opening of new businesses during this COVID-19 pandemic period in Brazil. A qualitative study, of a descriptive nature, with an investigative method based on basic qualitative research. The data collection was done through a focus group, applying a semi-structured interview to a group of nine participants, and the data were submitted to the Analysis of Nucleus of Sense, with the aid of the software IRAMUTEQ. The results showed that entrepreneurs saw new opportunities through digital social networks (Instagram, Facebook and WhatsApp), motivated by curiosity and the opportunity provided by the COVID-19 pandemic. The research evidence contributes to an entrepreneurial awakening, which seeks to seize opportunities and reach the challenging market. Once aware of the opportunities and the pent-up demand of the consuming public through social networks, new Marketing strategies can
\end{abstract}


be adopted to leverage the new ventures and meet the expectations of consumers limited by the mobility restrictions and social relations imposed during the pandemic.

Keywords: Entrepreneurship; COVID-19; Opportunities; Pandemic.

\section{Resumo}

Este artigo tem como objetivo investigar a abertura de novos negócios durante o período pandêmico do COVID-19 no Brasil. Estudo qualitativo, de natureza descritiva, com método investigativo baseado em uma pesquisa qualitativa básica. A coleta de dados foi realizada por meio de grupo focal, aplicando-se entrevista semiestruturada a um grupo de nove participantes, e os dados foram submetidos à Análise de Núcleos de Sentido, com auxílio do software IRAMUTEQ. Os resultados mostraram que os empreendedores enxergam novas oportunidades por meio das redes sociais digitais (Instagram, Facebook e WhatsApp), motivados pela curiosidade e pela oportunidade proporcionada pela pandemia COVID-19. As evidências da pesquisa contribuem para um despertar empreendedor, que busca aproveitar as oportunidades e atingir o mercado desafiador. Uma vez cientes das oportunidades e da demanda reprimida do público consumidor por meio das redes sociais, novas estratégias de Marketing podem ser adotadas para alavancar os novos empreendimentos e atender às expectativas dos consumidores limitados pelas restrições de mobilidade e relações sociais impostas durante a pandemia.

Palavras-chave: Empreendedorismo; COVID-19; Oportunidades; Pandemia.

\section{Resumen}

Este artículo tiene como objetivo investigar la apertura de nuevos negocios durante el período de la pandemia COVID19 en Brasil. Estudio cualitativo, de carácter descriptivo, con un método investigativo basado en la investigación cualitativa básica. La recolección de datos se realizó a través de un grupo focal, aplicando una entrevista semiestructurada a un grupo de nueve participantes, y los datos se sometieron a Sense Nucleus Analysis, con la ayuda del software IRAMUTEQ. Los resultados mostraron que los emprendedores ven nuevas oportunidades a través de las redes sociales digitales (Instagram, Facebook y WhatsApp), motivados por la curiosidad y la oportunidad que brinda la pandemia COVID-19. La evidencia de la investigación contribuye a un despertar empresarial, que busca aprovechar las oportunidades y llegar al mercado desafiante. Dado que las oportunidades de oportunidades y la demanda reprimida de los consumidores públicos a través de las redes sociales, no existen estrategias de marketing, se pueden adoptar para apalancar nuevos emprendimientos y satisfacer las expectativas de los consumidores limitados, las restricciones de movilidad y las relaciones sociales impuestas durante una pandemia.

Palabras clave: Emprendimiento; COVID-19; Oportunidades; Pandemia.

\section{Introduction}

In the current evolution of the pandemic, it is impossible to measure the true impact of the Corona Virus 2019 (COVID-

19) Pandemic on Global Entrepreneurship. Even with the increase in demand for medical products, there are sectors that have been hit hard, namely: trade in general, entertainment, tourism and hospitality, the production chain and the consumer supply chain, among others. It is estimated that, among Fortune 1000 companies, 94\% were affected by Covid-19 (Fortune, 2020).

The pandemic has changed the reality of all countries, products and services started to be offered by companies in the online format, using the delivery service through applications and social networks as the main form of communication with customers. This is a moment of paradigm shifts in all aspects of life, as well as in organizations (virtual and face-to-face), this being the watershed moment for businesses and customers (Andrade Carneiro, Rodrigues, França, Prata, 2020)

Organizations around the world face the same challenge with the closure of services that are not considered "essential". The reality in Brazil has not been different from the rest of the world, the challenge faced by businesses is enormous, especially for small and medium-sized companies, that is, the herculean entrepreneur. COVID-19 hit this group strongly, for the simple fact that the vast majority are workers with less purchasing power and with a lower degree of knowledge. A survey carried out by SEBRAE in April 2020 found an $88 \%$ drop in small business revenue.

However, there is a significant increase in the opening of online businesses. According to Época Negócios magazine, in just over two months of the pandemic, Brazil registered the opening of more than one virtual store per minute. Opening up ventures in times of a pandemic is a greater challenge than surviving in "normal" times. In this regard, given the scenario presented, this research aims to investigate the opening of new businesses during the COVID-19 pandemic in Brazil. 
This research is justified by the need to get to know the entrepreneurs who sought, in the crisis, an opportunity to take their business forward. In addition, this research aims to contribute academically, in view of the scarcity of studies on this topic, since most of the research that has been carried out has been concentrated in the health area. Empirically, it contributes in order to get to know these new entrepreneurs, their difficulties, motivations and perceptions. Thus, the following research question arises: How has the experience of entrepreneurship in Brazil been during the pandemic and economic crisis scenario? To answer the research question and achieve its objective, it was decided to conduct qualitative research through a focus group.

\section{Entrepreneurship and COVID-19}

Entrepreneurship can be conceptualized as the integration of individuals and processes, which together transform ideas into opportunities (Dornelas, 2018), adding, the ability to perform with creativity, motivation, innovation, with proactive behavior and willing to take risks, would be the awakening of the individual from his potentialities, in a permanent learning process (Neto et al., 2020, p. 3).

COVID-19 is a new pandemic that spreads mainly through contact with infected people through coughing or sneezing. The COVID-19 outbreak began in China and then spread around the world, which contributed to the large number of deaths (397,388 deaths, 8 June 2020, WHO). COVID-19 is a disease with respiratory causes and symptoms such as cough, fever and, in more severe cases, difficulty in breathing or shortness of breath (Bakar \& Rosbi, 2020), so it impacts all working models, and even entrepreneurship, as shown in Figure 1, which brings a vision from individual microentrepreneurs.

Figure 1: Individual Entrepreneurs in Brazil.

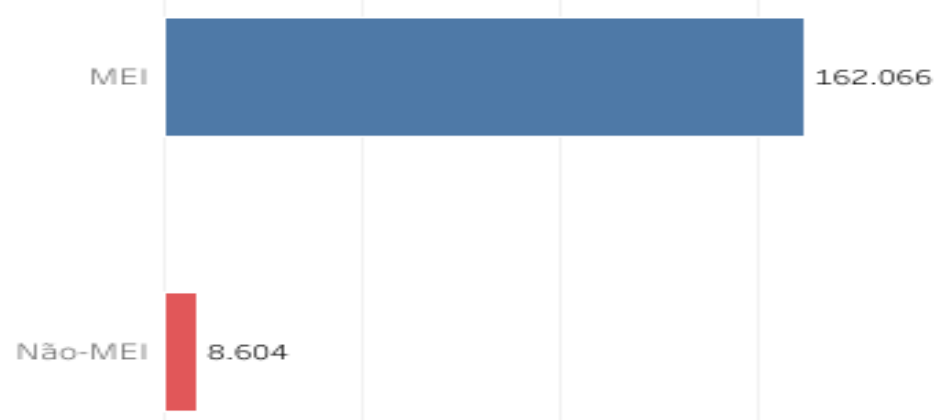

Source: National Registery of Legal Entities (CNPJ) - Digital Government (2020).

Figure 1 shows how much individual microentrepreneurs are present in the economy, compared to other types of enterprises, and therefore may be more affected by the pandemic because they depend on their own efforts. While many companies went bankrupt and several shopping center (or mall in American English) lease contracts were negatively impacted by COVID-19, some entrepreneurs found new business models as an opportunity to take advantage of the pent-up demand of the trade that was forced to close their doors for customers in this period of pandemic and restricted circulation of the population (Terra, 2020, Gama Neto, 2020). On June 25, 2020, the Digital Government (2020) presented the report of all companies included in the National Registery of Legal Persons (CNPJ) in Brazil, with a total of 18,604,168 active companies, of which 201,867 were opened this year and 67,108 were terminated for several reasons.

In Brazil, the number of legalized individual microentrepreneurs registered with the competent government agencies is 162,066. This number can be directly impacted by the pandemic, since this entrepreneur depends directly on his productivity. Although the number of entrepreneurs is significant, in real life, about $80 \%$ are informal (Neto et al., 2020, Sheperd, 2020).

The profile of the entrepreneur in Brazil has the age of 18 as the most frequent starting point, with this frequency reducing at age 64 , the age limit in the spectrum of entrepreneurial action, with $37.5 \%$ of these entrepreneurs being entrepreneurs 
out of necessity, according to a study by the Global Entrepreneurship Monitor (GEM) research program in 2018, that is, they decided starting a business because they had no other job options. While others work in entrepreneurship for pure opportunity, these in turn are involved with entrepreneurship because they have identified a business opportunity they wanted to pursue (Neto et al., 2020; Rezende \& Marcelino, 2020).

Entrepreneurship by necessity has been associated with conditions of falling economic activity, which generates unemployment and decreases employment opportunities. The occurrence of this scenario has driven people to start an economic activity that makes their economic survival possible. At the same time opportunity entrepreneurship has been characterized as the Schumpeterian entrepreneur, due to its holistic vision, ability to innovate and create new opportunities to find new customers through technology, applications and social networks (Deshmukh \& Hallem, 2020).

And the current pandemic scenario influences the following reality: (a) working from home remotely and with virtual meetings by videoconference, (b) strong connection of the virtual and physical world, (c) the definition of the opening of essential sectors by the Ministry of Health, (d) technology and the internet will function as powerful facilitators in business. That is, given the above, entrepreneurship by opportunity has greater notoriety (Bezerra, do Espírito Santo, Monteiro, Muto, 2020).

To facilitate the development of new entrepreneurs by opportunity, SEBRAE (2019) launched several projects to train, free of charge, all persons classified as Individual Microentrepreneurs (MEI), and those who work for themselves and seek legalization as an entrepreneur opting for a simple format, allowed a gross annual revenue equal to or less than $\mathrm{R} \$ 81,000.00$ (Eighty-One Thousand Reais), are included in this profile.

Stangherlin, Moraes and Oliveira (2020) developed practical and updated guidelines on online sales, e-commerce, and on how to use social networks strategically. Such guidelines respond to the demands of today's consumers, who are more connected and digital (Li-Ying \& Neil, 2020).

\section{Methodology}

This research has a descriptive nature (Gil, 2008) and a qualitative approach, taking into account that the researcher is the key tool to interpret the observed phenomena and describe them, identifying their important points and providing descriptions to subjective data, which largely cannot be measured statistically (Prodanov \& Freitas, 2013). The choice of the approach used was based on the idea that the authors understand the interviewees' perceptions so that their results do not derive from hasty conclusions and distort their work (Taquette, 2016). In addition, the present work is configured as a Basic Qualitative Research (Merriam, 1998), and the profile of its participants is presented in Table 1. 
Table 1: Characteristics of the focus group participants.

\begin{tabular}{|c|c|c|c|c|}
\hline Guests & Age years & Level education & City - State & Genre \\
\hline C2 & 35 & Postgraduate & Teresina- Piauí & Female \\
\hline C3 & 24 & Bachelor`s Degree & Teresina- Piauí & Female \\
\hline C4 & 38 & Bachelor`s Degree & Floriano- Piauí & Male \\
\hline C5 & 28 & High school & Teresina- Piauí & Male \\
\hline C6 & 38 & Bachelor`s Degree & Teresina- Piauí & Female \\
\hline C7 & 49 & High school & Teresina- Piauí & Female \\
\hline C8 & 26 & Bachelor`s Degree & Teresina- Piauí & Female \\
\hline C9 & 38 & Doctorate & Picos-Piauí & Male \\
\hline
\end{tabular}

Source: Own authorship (2020).

The authors' network of contacts via Instagram and WhatsApp were the focus of this research. Six young women under 50 years old and three men under 40 years old (Table 1), were the profiles presented as participants of the research with the purpose of raising the answers to the elaborated questions. To select the participants, the following filter question was decided on: "Who operated/opened ventures during the pandemic period COVID-19?"

There were no limitations to the respondents regarding the level of education, purchasing power or age. Since the profiles found have a diversity of both age, as well as the level of education and regionalism, some have high school and are pursuing graduation, some graduates, others have a master's or doctorate. Eight are from the state of Piauí, between the cities of Floriano, Picos and the capital Teresina.

Data collection was carried out through a focus group. In the focus group, the interviewer acts as a group mediator, raising a specific topic and facilitating a process of open and informal conversation with his interviewees until he collects the necessary data for the conclusion of the research (Gil, 2008).

The focus group was conducted virtually, due to the pandemic, through WhatsApp and Instagram with the virtual presence of 12 people: 8 guests (participants is better), who provided the data for this research; the supervisor of this project, who fulfilled the role of facilitator, responsible for controlling the virtual conversation and raising topics; and the authors, who participated as a support in the interaction.

To facilitate the discussion among the participants, the facilitator used a guide with 15 questions formulated by the author of this research project, aiming to keep the conversation between the guests pertinent to the theme and raising questions that involve specific topics: demographic data; first contact with entrepreneurship and influencing network; relationship with business planning; difficulties during the new normal; growth expectation; technology, social networks and applications.

For the analysis of the data, the Core Analysis Method, based on Bardin (2002), was used, which seeks information through the categorization of empirical data such as texts and messages. After the application of the focus group, the next step consisted of cleaning the data sent by the participants so that it was possible to discover the themes through the use of the Iramuteq software that supported the author in the textual analysis phase to which the data were submitted, promoting the investigation of specific groups of texts and words, their hierarchical classification, similarity analyzes, among other analyzes.

Said software has statistical rigor and is suitable for analyzing the symbolic content of textual materials (Camargo \& Justo, 2013). The validity and reliability of the research were assessed through peer review and a detailed and dense description to transmit the results (Merriam, 1998). 


\section{Results and Discussions}

The results of submitting the textual corpus to descriptive analysis resulted in a division of 108 text segments, with a total of 1927 numbers of occurrences, that is, the total number of words within the corpus, with 483 differentiated words and 281 hapax, forms which are repeated only once within the content. In this research, the authors chose to use the similarity analysis.

\subsection{Similitude analysis}

Using a content analysis (Bardin, 2016; Marques, 2021), it was possible to extract the speeches of the interviewees and classify by segments of similarity and frequency of the speeches along these lines. The words were also grouped into "communities", which represent the groups of words that are most associated in each branch, whose most representative words are: company; pandemic; entrepreneur; undertake; begin; planning; new; store. For didactic reasons, the authors of this research presented the communities by subgroups, as illustrated by the following subtopics.

\subsubsection{Subgroup 1}

From the studies assimilated about the relationships presented in subgroup 1 of the similarity map, it can be inferred that: it is composed of words that express moments in the lives of entrepreneurs, where they perceived the opportunity in the middle of the pandemic and to adapt to the new technologies that emerged in society due to complications that they experienced in their day-to-day lives, such as delivery being accessed by applications via the internet, as well as the need to supplement their income, even though some already have another source of income. This is perceived by the connection between the words: pandemic, rather, activity, pay, exercise, as shown in image 3.

Based on this, you can capture a section where these words are expressed:

I realized that I could open my venture during the quarantine period, because due to the pandemic I started to face new challenges after being fired from the old company. I was not an entrepreneur before the pandemic. Entrepreneurship in the new normal is challenging and very grueling $(\mathrm{C} 1)$.

After the negative events generated by the pandemic (Fortune, 2020), C1 decided to face the difficulties he had and chose to dive deeper into that world. Determined, she did strategic planning and prepared herself for periods of raw material scarcity: "I was aware that it was an unusual situation and that I had to readjust how to not have the studio now, work providing production that was unplanned for and understand that raw material would be scarce during the pandemic".

C3 expresses the desire to undertake and expand sales (Dornelas, 2018), when reporting on entrepreneurship in the pandemic:

I was never an entrepreneur before the pandemic. However, the biggest incentive for me to be an entrepreneur is my grandparents, my aunt, and my mother. The moment when I realized that I could open my venture was right after participating in the Empretec (SENAC) course, I was prepared to face new challenges, even with the pandemic.

The words: new normal and time are also perceived. "Opening a venture/facing new challenges in the new normal is not easy. Now we must stay connected much longer but at the same time we need to visit the companies and understand the need of the company through an on-site visit and some do not want to receive us face-to-face due to the pandemic" (C4). 


\subsubsection{Subgroup 2}

Subgroup 2 has a meaning in the community, words like family, parents, husband, uncle and are the most prominent in their sets. Some refer to the interaction between generations. Figure 4 illustrates the connection between them.

Based on the analysis of the opinions of the participants, the entrepreneurial profile that shows strong encouragement from family members is revealed "My biggest incentive to be an entrepreneur came from my husband, and we carried out all the initial planning, before the opening of the first store, we strived to structure ourselves with our own working capital and we did an analysis on where our target audience would be. During the pandemic we had to intensify online sales, we worked with reduced staff, we increased investment in advertising. To undertake in this new normal is to innovate every day, to always keep customers informed with news, to work in sales and after sales" (C6).

This point was also commented on in the research by Neto et al., (2020), which is based on the awakening of the individual to his potentialities, in a permanent learning process:

"In the midst of this crisis, I realized that I could profit from the food business. The company started by selling hamburgers to friends. We had no initial planning, we started our venture and we improved. I had to change hygiene and delivery in this pandemic period. Operating in the new normal is very difficult due to the accessibility of the products. Yes, after the pandemic I intend to have our company at a physical address.” (C5).

The DIGITAL GOVERNMENT (2020) presented the report of all companies inserted in 2020, but it does not demonstrate the Brazilian reality regarding the real number of active entrepreneurs, even in this pandemic time it is proven that many of these entrepreneurs found opportunities to face the challenges without being legalized.

\subsubsection{Subgroup 3}

Subgroup 3 has a cluster of communities, words like entrepreneurship, new, opportunity and social network. Image 5 illustrates the connection between them.

The connection between planning, company opening, entrepreneurial profile is linked to a holistic view, the ability to innovate and create new opportunities to find new customers through technology, applications and social networks (Deshmukh and Haleem, 2020). "The company I started during the pandemic arose out of opportunity entrepreneurship, when gifts made by me were promoted by family members, requests from customers who became interested in the product started to appear, so I decided to turn the opportunity into a virtual craft store, I believe that without using social networks, my company would not have grown" (C7).

"People are increasingly on social networks, I joined opportunities through the skill of my daughters at home with design, journalism, social media and administration and invested in marketing, packaging and planning, so, from the first day of the store opening, we brought a differential to the posts in the craft sector, generating engagement and a lot of orders, it surprised us at first, the first thirty days were crazy, to operate with new care and new challenges is frightening at first, but good planning of all stages is essential for greater security in times of crisis" (C8). (I think this is way too long for one sentence only - at least in English).

From then on, it can be inferred that the participants unconsciously revealed that operating in times of a pandemic may have been the opportunity for new markets to be served and for them to evolve personally.

\section{Conclusions}

The main influencing factor for entrepreneurship to happen in times of a pandemic was family members who already owned some type of company, and consequently encouraged the opening of new businesses, even though they needed to adapt 
to new ways of working and attracting customers through technology. Whereupon for some it would be an income supplement, for many others, entrepreneurship has been a way of providing new results for the dynamic demands of the market.

The research results contribute by bringing new insights to studies involving entrepreneurship, performance and new practices through technologies, by not only selling online, but connecting consumers to the new lifestyle model, supported by social networks and applications. Once they are aware of the opportunities and the pent-up demand of the consumer public through social networks, new marketing strategies can be adopted to leverage new ventures and meet consumer expectations limited by the mobility restrictions and social relations imposed during the pandemic.

It is suggested that future research projects approach a different perspective from the one focused on in this work, with quantitative analysis as a typology, which will allow generalization of results. It is also recommended that further investigation be carried out in relation to post-pandemic entrepreneurship, as well as in different environments with different technological resources. Finally, another suggestion focuses on investigating the influence of the pandemic on the process of closing companies of virtual and physical entrepreneurs, a point not addressed in this research.

\section{References}

Baggio, A. F., \& Baggio, D. K. (2014). Empreendedorismo: Conceitos e definições. Revista de Empreendedorismo, Inovação e Tecnologia, 1(1), 25- 38. https://doi.org/10.18256/2359-3539/reit-imed.v1n1p25-38

Bakar, N. A., \& Rosbi, S. (2020). Effect of Coronavirus disease (COVID-19) to tourism industry. International Journal of Advanced Engineering Research and Science, 7(4).

Bardin, L. (2016). Análise do conteúdo. Tradução de Luís Antero Reto e Augusto Pinheiro. Edições 70.

Bezerra, D. R. C., do Espírito Santo, F. H., Monteiro, J. K. D. M. F., \& Muto, T. S. (2020). Os vulneráveis no período do COVID-19: uma revisão integrativa de literatura. Research, Society and Development, 9(10), e4699108860-e4699108860.

Camargo, B. V., \& Justo, A. M. (2013). IRAMUTEQ: um software gratuito para análise de dados textuais. Temas em psicologia, $21(2), 513-518$.

de Andrade Carneiro, L., Rodrigues, W., França, G., \& Prata, D. N. (2020). Uso de tecnologias no ensino superior público brasileiro em tempos de pandemia COVID-19. Research, Society and Development, 9(8), e267985485-e267985485.

Deshmukh, S. G., \& Haleem, A. (2020). Framework for Manufacturing in Post-Covid-19 World Order: An Indian Perspective. International Journal of Global Business and Competitiveness, p. 1. https://doi.org/10.1007/s42943-020-00009-1

Dornelas, J. C. A. (2018). Introdução ao Empreendedorismo: Desenvolvendo habilidades para fazer acontecer. Empreende.

Fortune (2020). Fortune as 1000 empresas e o covid-19. 2020. <https://fortune.com/2020/02/21/fortune-1000-coronavirus-china-supply-chain-impact/on>.

Gama Neto, R. B. (2020). Impactos da COVID-19 sobre a economia mundial. Boletim de Conjuntura (BOCA), 2(5), $113-127$. http://doi.org/10.5281/zenodo.3786698

Gil, A. C. (2008). Métodos e técnicas de pesquisa social. (6a ed.), Atlas.

Governo Digital (2020). https://www.gov.br/governodigital/pt-br/mapa-de-empresas/painel-mapa-de-empresas

Li-Ying, J., \& Nell, P. (2020). Navigating opportunities for innovation and entrepreneurship under COVID-19. California Management Review, 63(1).

Marques, M. U. E. D. B. (2021). Análise de conteúdo. Clube de Autores.

Merriam, S. (1998). Qualitative Research and Case Study Applications in Education. Jossey-Bass.

Nassif, V. M. J., Corrêa, V. S., \& Rossetto, D. E. (2020). Estão Os Empreendedores E As Pequenas Empresas Preparadas Para As Adversidades Contextuais? Uma Reflexão À Luz Da Pandemia Do Covid-19. Revista de Empreendedorismo e Gestão de Pequenas Empresas, 9(2).

Neto, M. N. F., Castro, J. L. C., Queiroz, A. M. G., Neto, R. G., \& Almeida, S. R. B. (2020). As causas da informalidade dos micros e pequenos empreendedores na perspectiva do profissional de contabilidade. Empreendedorismo, Gestão e Negócios, 9(9), 578-591.

Organização Mundial da Saúde (OMS, 2020). Coronavirus disease (COVID-19) Pandemic. 2020. <https://www.who.int/emergencies/diseases/novelcoronavirus-2019>. Acesso em: 26 de junho de 2020.

Prodanov, C. C., \& Freitas, E. C. (2013). Metodologia do trabalho científico: Métodos e técnicas da pesquisa e do trabalho acadêmico. (4a ed.), Feevale.

Rezende, A. A., Marcelino, J. A., \& Miyaji, M. (2020a). A reinvenção das vendas: as estratégias das empresas brasileiras para gerar receitas na pandemia de COVID-19. Boletim de Conjuntura (BOCA), 2(6), 53-69. http://doi.org/10.5281/zenodo.3834095 
Research, Society and Development, v. 10, n. 15, e379101522574, 2021

(CC BY 4.0) | ISSN 2525-3409 | DOI: http://dx.doi.org/10.33448/rsd-v10i15.22574

Serviço Brasileiro de Apoio às Micro e Pequenas Empresas (SEBRAE, 2018). Pequenos negócios em números. http://www.sebrae.com.br/sites/PortalSebrae/ufs/sp/sebraeaz/pequenos-negocios-emnumeros,12e8794363447510VgnVCM1000004c00210aRCRD.

Shepherd, D. A. (2020). COVID 19 and entrepreneurship: Time to pivot? Journal of Management Studies.

Stangherlin, A., MORAES, Daniel João de, \& Oliveira, J. N. D. (2020). Os desafios enfrentados pelos pequenos empreendedores durante a pandemia da COVID-19. Observatório socioeconômico da COVID-19. UFMS.

Taquette, S. R. (2016). Análise de dados de pesquisa qualitativa em saúde. $5^{\circ}$ Congresso Ibero-Americano em Investigação Qualitativa - CIAIQ2016, 2.

Terra, A. M. V. (2020). Covid-19 e os contratos de locação em shopping center. https://www. migalhas. com. br. 